\title{
Studies on the Reactivity of the Aminophosphino
}

$\left[\mathrm{W}_{3} \mathrm{~S}_{4} \mathrm{Br}_{3}(\mathrm{edpp})_{3}\right]^{+}$(edpp= (2-aminoethyl)diphenylphosphine)

\section{Cluster Cation towards Bases Revealing a Non-Passive Role of} the Amino Group

\author{
Jose A. Pino-Chamorro, ${ }^{[a]+}$ Tomás F. Beltrán, ${ }^{[b]+}$ M. Jesús Fernández-Trujillo, ${ }^{[a]}$ Manuel G. Basallote, ${ }^{*[a]}$ \\ Rosa Llusar, ${ }^{*[b]}$ and Andrés G. Algarra*[a]
}

\begin{abstract}
Detailed studies using stopped-flow, ${ }^{31} \mathrm{P}\left\{{ }^{1} \mathrm{H}\right\} \mathrm{NMR}$, and ESI-MS have been carried on the reaction of the $\left[\mathrm{W}_{3} \mathrm{~S}_{4} \mathrm{Br}_{3}(\mathrm{edpp})_{3}\right]^{+}$ (edpp $=(2$-aminoethyl)diphenylphosphine) cluster with $\mathrm{NaOH}$ and $\mathrm{Et}_{3} \mathrm{~N}$ in acetonitrile. The study has allowed identification of hydroxo species during the reactivity studies and the development of a procedure for the synthesis of the $\left[\mathrm{W}_{3} \mathrm{~S}_{4}(\mathrm{OH})_{3}(\mathrm{edpp})_{3}\right]^{+}$cluster in high yields. This involves the substitution of the coordinated bromides by $\mathrm{OH}^{-}$ligands, and the associated kinetics is several orders of magnitude faster than that with $\mathrm{Cl}^{-}, \mathrm{F}^{-}$, and $\mathrm{SCN}^{-}$anions. The reactivity with $\mathrm{Et}_{3} \mathrm{~N}$ is quite different and essentially leads to the formation of species resulting from proton abstraction at the $\mathrm{NH}_{2}$ groups of the edpp ligands, the amine acting as a base. DFT calculations provide a rationalization of the experimental findings by showing that $\mathrm{Et}_{3} \mathrm{~N}$ coordination does not occur even in the presence of a vacant coordination site. Computed pKa values for the different species involved in these reactions indicate the possibility of proton exchange between the $\mathrm{NH}_{2}$ groups of edpp and $\mathrm{Et}_{3} \mathrm{~N}$, which is confirmed by the NMR and ESI-MS data. The formation of intermediate cluster species containing the conjugate base of edpp has been also found to facilitate bromide dissociation, thus providing a reaction pathway with a lower energy barrier that justifies the faster formation of $\left[\mathrm{W}_{3} \mathrm{~S}_{4}(\mathrm{OH})_{3}(\mathrm{edpp})_{3}\right]^{+}$with respect to other $\left[\mathrm{W}_{3} \mathrm{~S}_{4} \mathrm{X}_{3}(\mathrm{edpp})_{3}\right]^{+}(\mathrm{X}=\mathrm{Cl}, \mathrm{F}$, $\mathrm{SCN}$ ) clusters.
\end{abstract}

\section{Introduction}

Transition metal sulfide compounds are involved in highly relevant industrial and biological catalytic processes. Molybdenum disulfide is widely used as heterogeneous catalysis for the

[a] Dr. J. Á. Pino-Chamorro, Prof. M. J. Fernández-Trujillo, Prof. M. G. Basallote, Dr. A. G. Algarra

Departamento de Ciencia de los Materiales e Ingeniería Metalúrgica y Química Inorgánica, Facultad de Ciencias, Instituto de

Biomoléculas, Universidad de Cádiz, 11510 Puerto Real, Cádiz,

Spain. E-mail: manuel.basallote@uca.es; andres.algarra@uca.es

[b] T. F. Beltrán, Prof. R. Llusar

Department de Química Física i Analítica, Universitat Jaume I, Av.

Sos Baynat s/n, 12071 Castelló, Spain. E-mail: llusar@uji.es

$\dagger \quad$ These authors contributed equally to this work.

Supporting information for this article is given via a link at the end of the document. It contains results from kinetic, NMR and ESI-MS experiments, electronic and Gibbs free energies for all the computed species and Cartesian coordinates of the optimized structures. hydrodesulfurization of fossil fuels in the presence of hydrogen, while sulfur containing metaloenzymes participate in the initial reduction reaction of molecular nitrogen. 1 On the other hand trinuclear molybdenum cluster sulfides cluster complexes catalyze the photogeneration of hydrogen from water when coupled to a semiconductor such as p-type silicon, titanium dioxide. - $-3^{-3}$ In collaboration with Beller's group, some of us have recently investigated the catalytic performance of $\mathrm{Mo}_{3} \mathrm{~S}_{4}$ complexes functionalized with diphosphine, diamine and diimine ligands in the hydrogenation and transfer hydrogenation of nitroarenes. $\stackrel{4-6}{ }$ Moreover, group six $\mathrm{M}_{3} \mathrm{~S}_{4}$ clusters also catalyze the selective hydrodefluorination of pentafluoropyridine in the para position by using silanes as hydrogen source. $\frac{7-8}{}$

Developing efficient and selective homogeneous catalysts require a full understanding of the reaction mechanism. In this context, the combination of stopped-flow, NMR, and mass-spectrometry techniques represents a powerful approach to analyse the solution behaviour and the kinetics of inter-conversion between different chemical species. This is clearly illustrated by our mechanistic studies on the proton transfer reactions between diphosphino trinuclear $\mathrm{M}_{3} \mathrm{~S}_{4}(\mathrm{M}=\mathrm{Mo}, \mathrm{W})$ hydride clusters and acids, which support the initial formation of dihydrogen-bonded adducts that then evolve to substitution products with $\mathrm{H}_{2}$ release. ${ }^{9}$ 12 This finding led us to investigate, as previously mentioned, the catalytic activity of these systems in the reduction of nitroderivatives to selectively obtain amines in high yieds..-6

On the other hand, amino phosphine complexes have emerged as bifunctional catalysts that rely on metal-ligand cooperation. .3 16 In all the cases reported to date, coordination of this kind of ligands to the cuboidal $\mathrm{M}_{3} \mathrm{~S}_{4}$ cluster unit invariably occurs with the phosphorous atoms trans to the capping sulfur, as depicted in Figure 1 for the (2-aminoethyl)diphenylphosphine (edpp) derivatives..$^{17-19}$ Thus, the nitrogen atoms of the amino groups and the $X$ ligand are located on the same side of the trimetallic plane in the crystal structures of the $\left[\mathrm{M}_{3} \mathrm{~S}_{4} \mathrm{X}_{3}(\mathrm{edpp})_{3}\right]^{+}(\mathrm{M}=\mathrm{Mo}, \mathrm{W} ; \mathrm{X}=$ halide or pseudohalide) cations.

The substitution mechanism of the $X$ ligand in $\left[\mathrm{W}_{3} \mathrm{~S}_{4} \mathrm{X}_{3}(\mathrm{edpp})_{3}\right]^{+}$ strongly depends on the nature of leaving and entering anions, with the interactions between $\mathrm{X}$ and the proton atoms of the amino group also affecting the kinetics of the process. $\frac{17}{\text { Gas }}$ phase reactivity studies on molybdenum $\left[\mathrm{Mo}_{3} \mathrm{~S}_{4} \mathrm{X}_{3}(\mathrm{edpp})_{3}\right]^{+}(\mathrm{X}=\mathrm{Cl}, \mathrm{Br})$ clusters have shown the sequential elimination of neutral $\mathrm{HX}(\mathrm{X}=$ $\mathrm{Cl}, \mathrm{Br}$ ) molecules under collision induced dissociation (CID) conditions, suggesting the formation of molybdenum/imine $\mathrm{Mo}=\mathrm{NH}$ species, a result supported by DFT calculations. ${ }^{19}$ In fact, 
the relevance of the $\mathrm{M}-\mathrm{NH}$ group in catalysis comes from cooperation between the $\mathrm{N}-\mathrm{H}$ proton and the other metal bonded ligands. $\underline{20}$

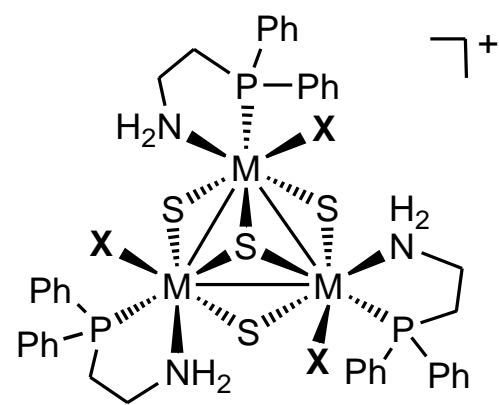

Figure 1. Structure of $\left[\mathrm{M}_{3} \mathrm{~S}_{4} \mathrm{X}_{3}(\operatorname{edpp})_{3}\right]^{+}$cations $(\mathrm{M}=\mathrm{Mo}, \mathrm{W} ; \mathrm{X}=$ monodentate ligand).

Bases have been found to be critically important for the hydrogenation and transfer hydrogenation reactions catalyzed by aminophosphine metal complexes. $\frac{21-22}{2}$ This fact has led us to investigate the reactivity of the cuboidal aminophosphino $\left[\mathrm{W}_{3} \mathrm{~S}_{4} \mathrm{Br}_{3}(\mathrm{edpp})_{3}\right]^{+}$complex towards bases, in particular sodium hydroxide, tetrabutylaammonium hydroxide and triethylamine. Herein, we report the synthesis and crystal structure of the hydroxo $\left[\mathrm{W}_{3} \mathrm{~S}_{4}(\mathrm{OH})_{3}(\mathrm{edpp})_{3}\right]^{+}$cluster. Kinetic results for the reaction between the aminophosphine $\left[\mathrm{W}_{3} \mathrm{~S}_{4} \mathrm{Br}_{3}(\mathrm{edpp})_{3}\right]^{+}$cluster and both bases are also reported. These results are complemented with DFT calculations, and the whole set of data confirms the non-innocent role of the $\mathrm{NH}_{2}$ group within the edpp ligands.

\section{Results and Discussion}

\section{Synthesis and characterisation}

The reactivity of $\left[\mathrm{W}_{3} \mathrm{~S}_{4} \mathrm{Br}_{3}(\text { edpp })_{3}\right]^{+}\left(\mathbf{1}^{+}\right)$towards bases was first investigated by adding an aqueous sodium hydroxide solution to an acetonitrile solution of the cluster (equation 1):

$$
\left[\mathrm{W}_{3} \mathrm{~S}_{4} \mathrm{Br}_{3}(\mathrm{edpp})_{3}\right]^{+}\left(\mathbf{1}^{+}\right) \frac{\mathrm{NaOH}(\mathrm{aq}, \text { excess) }}{-3 \mathrm{NaBr}}\left[\mathrm{W}_{3} \mathrm{~S}_{4}(\mathrm{OH})_{3}(\mathrm{edpp})_{3}\right]^{+}\left(\mathbf{2}^{+}\right)
$$

The reaction occurs in acetonitrile-water (2:1) mixtures at room temperature with an immediate colour change from blue to purple and the formation of the hydroxo complex $2^{+}$in $86 \%$ yield. The facile formation of this species contrasts with the difficulties often encountered in the synthesis of transition metal complexes bearing terminal $-\mathrm{OH}$ ligands due to their tendency to decompose or oligomerize. $\frac{42-43}{}$ The stability of $\mathbf{2}^{+}$, as well as that of the closely related $\quad\left[\mathrm{W}_{3} \mathrm{~S}_{4}(\mathrm{OH})_{3}(\mathrm{dmpe})_{3}\right]^{+} \quad(\mathrm{dmpe}=1, \quad 2$ - bis(dimetylphosphinoethane) derivative, can be due to the bulkiness of the outer ligands that hinder oligomerization. $\underline{44}$

The structure of $\left(\mathbf{2}\left(\mathrm{BPh}_{4}\right)\right)$ has been determined by single crystal $\mathrm{X}$-ray diffraction methods. An ORTEP drawing of cation $\mathbf{2}^{+}$is represented in Figure 2.
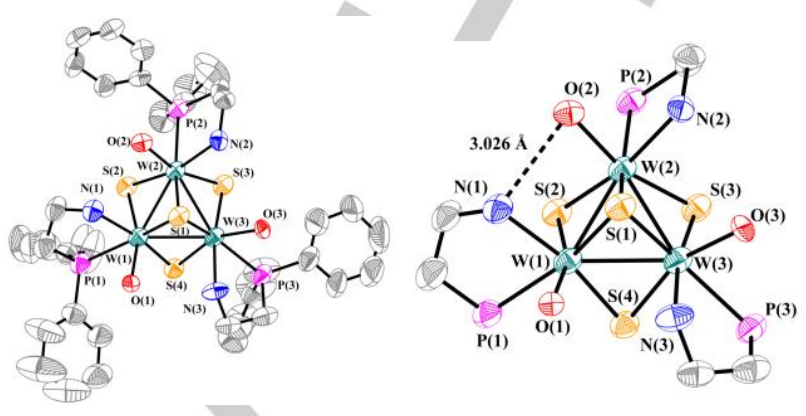

Figure 2. ORTEP representations of two different views of cation $\mathbf{2}^{+}$(ellipsoids at $50 \%$ probability). Hydrogen atoms have been omitted for clarity.

Metal and sulfur atoms in $\mathbf{2}^{+}$occupy adjacent vertices in a cube with a vacant metal position that results in an incomplete cubanetype structure. The three metal atoms define an approximately equilateral triangle with $\mathrm{W}-\mathrm{W}$ bond distances of 2.7532[7] $\AA$, in agreement with the presence of single metal-metal bonds and a +4 oxidation state for each metal. Cluster $2^{+}$retains the main structural features of its $\mathbf{1}^{+}$bromine precursor with the outer phosphorous atom of the aminophosphino ligand trans to the capping sulphur. Table 1 contains a list of relevant averaged bond lengths for $\mathbf{1}^{+}$and $\mathbf{2}^{+}$together with those of the closely related diphosphino $\left[\mathrm{W}_{3} \mathrm{~S}_{4}(\mathrm{OH})_{3}(\mathrm{dmpe})_{3}\right]^{+}$cluster cation for comparative purposes. There is an asymmetry in the $\mathrm{W}-(\mu-\mathrm{S})$ distances due to trans influence differences between the phosphorous or nitrogen atoms of the bidentate ligand, with that of the the other outer ligands, $\mathrm{Br}^{-}$and $\mathrm{OH}^{-}$.The metal-oxygen bond length of 2.151[7] $\AA$ in $\mathbf{2}^{+}$agrees with the presence of an hydroxo group and it is slightly longer than the distances observed for the $\mathrm{M}-\mathrm{O}$ bonds in $\left[\mathrm{Mo}_{3} \mathrm{~S}_{4}(\mathrm{dmpe})_{3}(\mathrm{OH})_{3}\right]^{+}, \underline{45}$ $\left[\mathrm{W}_{3} \mathrm{~S}_{4}(\mathrm{dmpe})_{3}(\mathrm{OH})_{3}\right]^{+\underline{44}}$ and $\left[\mathrm{Mo}_{3} \mathrm{~S}_{4}(\mathrm{tdci})_{3}\right]^{4+}(\mathrm{tdci}=1,3,5$-trideoxy1,3,5-tris(dimethylamino)-cis-inositol) complexes, $\underline{46}$ with average metal-oxygen distances of 2.032[3], 2.100 $\AA$ and $2.087 \AA$, respectively. Furthermore, this $\mathrm{W}-\mathrm{O}$ distance is significantly shorter than those found in $\left[\mathrm{M}_{3} \mathrm{~S}_{4}\left(\mathrm{PPh}_{3}\right)_{3} \mathrm{Cl}_{4}\left(\mathrm{H}_{2} \mathrm{O}\right)_{2}\right]$ complexes for the $\mathrm{M}-\mathrm{OH}_{2}$ bond, of ca. $2.25 \AA$ for $\mathrm{M}=\mathrm{W}$ and $2.27 \AA$ for $\mathrm{M}=\mathrm{Mo}$. $\underline{48}$

As emphasised in Figure 2, short $\mathrm{N} \cdots \mathrm{O}$ interactions ranging from 3.026 to $3.564 \AA$ are observed between the oxygen atom coordinated to one metal and the nitrogen atom of the amino group coordinated to the adjacent metal. The solid state structure of $2^{+}$is preserved in solution, as evidenced by their ${ }^{31} \mathrm{P}\left\{{ }^{1} \mathrm{H}\right\} N M R$ spectra registered in $\mathrm{CD}_{3} \mathrm{CN}$, which shows a single signal at 19.6 $\mathrm{ppm}$ in agreement with the presence of three equivalent phosphorous nuclei. 
Table 1. Selected averaged bond distances $(\AA)$ for $\left[\mathrm{W}_{3} \mathrm{~S}_{4}(\mathrm{OH})_{3}(\mathrm{dmpe})_{3}\right]\left(\mathrm{PF}_{6}\right),\left[\mathrm{W}_{3} \mathrm{~S}_{4} \mathrm{Br}_{3}(\mathrm{edpp})_{3}\right]\left(\mathrm{BPh}_{4}\right)$ and $\mathbf{2}\left(\mathrm{BPh}_{4}\right)$.

\begin{tabular}{|c|c|c|c|}
\hline Length $(\AA)^{\mathrm{a}}$ & {$\left[\mathrm{W}_{3} \mathrm{~S}_{4}(\mathrm{OH})_{3}(\mathrm{dmpe})_{3}\right]\left(\mathrm{PF}_{6}\right)^{\mathrm{e}}$} & {$\left[\mathrm{W}_{3} \mathrm{~S}_{4} \mathrm{Br}_{3}(\mathrm{edpp})_{3}\right]\left(\mathrm{BPh}_{4}\right)^{\mathrm{f}}$} & 2(BPh 4$)$ \\
\hline W-W & $2.769[10]$ & $2.7520[3]$ & $2.7532[7]$ \\
\hline$W-\mu_{3}-S(1)$ & $2.385[11]$ & $2.3450[16]$ & $2.364[3]$ \\
\hline$W-\mu-S(2)^{b}$ & $2.331[4]$ & $2.3117[15]$ & $2.333[3]$ \\
\hline$W-\mu-S(2)^{c}$ & $2.343[10]$ & $2.3091[15]$ & $2.321[3]$ \\
\hline$W-P(1)^{d}$ & $2.513[18]$ & $2.5306[16]$ & $2.528[3]$ \\
\hline W-N & - & $2.286[5]$ & $2.278[8]$ \\
\hline $\mathrm{W}-\mathrm{X}(\mathrm{X}=\mathrm{Br}, \mathrm{OH})$ & $2.100[6]$ & $2.6401[7]$ & $2.151[7]$ \\
\hline
\end{tabular}

[a] Standard deviations for averaged values are given in square brackets. [b] $\mathrm{W}-(\mu-\mathrm{S})$ distance trans to $\mathrm{W}-\mathrm{X}$ bond. [c] W-( $\mu-\mathrm{S})$ distance trans to W-P(2) $\left(\left[\mathrm{W}_{3} \mathrm{~S}_{4}(\mathrm{OH})_{3}(\mathrm{dmpe})_{3}\right]^{+}\right)$or $\mathrm{W}-\mathrm{N}\left(\left(\left[\mathrm{W}_{3} \mathrm{~S}_{4} \mathrm{Br}_{3}(\mathrm{edpp})_{3}\right]^{+}\right.\right.$and $\left.2^{+}\right)$) bonds. [d] Distance trans to the $W-\left(\mu_{3}-S\right)$ bond. [e] From ref. ${ }_{4}^{4}$. [f] From ref. 1

\section{The reactivity of $1^{+}$towards bases}

To obtain additional data on the formation of the trihydroxo cluster $\mathbf{2}^{+}$, the kinetics of reaction between $\mathbf{1}^{+}$and $\mathrm{OH}^{-}$was initially studied at $25.0^{\circ} \mathrm{C}$ using the stopped-flow technique in acetonitrile-water mixtures containing $10 \%(\mathrm{w} / \mathrm{w})$ of water. However, under these conditions the reaction resulted to be too fast for the stopped-flow technique, and the spectrum recorded immediately upon mixing both reactants already showed the formation of $2^{+}$. Although some slow spectral changes were observed at longer times, they can be attributed to secondary decomposition or precipitation processes. In order to carry out kinetics studies in acetonitrile solution at lower temperatures, $\mathrm{NaOH}$ was replaced by $\mathrm{Bu}_{4} \mathrm{NOH}$. Note that, although commercial $\mathrm{Bu}_{4} \mathrm{NOH}$ contains some water, the final water concentration in the stock solutions was small enough (ca. $0.04 \%$ ) to allow measurements at $-40.0{ }^{\circ} \mathrm{C}$. Nevertheless, under pseudo-first order conditions of base excess the kinetics of reaction still resulted too fast to be monitored. At this point, the concentration of $\mathrm{Bu}_{4} \mathrm{NOH}$ was decreased to values close to those of the cluster and under those conditions spectral changes showing the disappearance of $\mathbf{1}^{+}$were observed at $-40.0^{\circ} \mathrm{C}$ (see Figure 3). A satisfactory fit of these spectral changes required of a model with two kinetic steps, and the calculated spectra are shown in Figure S2. Because these experiments were carried out under non pseudo-first order conditions, it is probable that these two steps correspond to the formation of intermediate species with partial replacement of $\mathrm{Br}$ by $\mathrm{OH}^{-}$, since there is not enough concentration of $\mathrm{OH}^{-}$to generate the trihydroxide cluster. Actually, the calculated spectra in Figure S2 agree well with those recorded for samples whose NMR spectra indicate the formation of the mono- and di-hydroxo compounds. By using several slightly different $\mathrm{OH}^{-}$to cluster ratios close to 1 , a value of $k_{1}=(2.8 \pm 0.2) \times 10^{2} \mathrm{M}^{-1} \mathrm{~s}^{-1}$ could be obtained for the first step at $-40.0^{\circ} \mathrm{C}$, the values for the second resolved step showing unsatisfactory reproducibility.

In a previous study we reported the kinetics of reactions of $\left[\mathrm{W}_{3} \mathrm{~S}_{4} \mathrm{X}_{3}(\mathrm{edpp})_{3}\right]^{+}\left(\mathrm{X}=\mathrm{Br}^{-}, \mathrm{Cl}^{-}, \mathrm{F}^{-}, \mathrm{SCN}^{-}\right)$clusters with different entering ligands $\left(\mathrm{Cl}^{-}, \mathrm{Br}^{-}, \mathrm{F}^{-}, \mathrm{SCN}^{-}\right)$using acetonitrile as solvent. ${ }^{17}$ It is important to note that there is a significant difference between those and the present kinetic studies, as shown by the fact that, while the rate constants for the thiocyanate and fluoride substitution are $0.16 \pm 0.01 \mathrm{M}^{-1} \mathrm{~s}^{-1}$ and $(2.6 \pm 0.6) \times 10^{3} \mathrm{M}^{-1} \mathrm{~s}^{-1}$ at $25.0^{\circ} \mathrm{C}$, the value for the hydroxide substitution is meaningfully faster given the large temperature difference between both studies.

Figure 3. Spectral changes for the reaction of $\mathbf{1}^{+}$with $\mathrm{Bu} 4 \mathrm{NOH}$ in acetonitrile (T

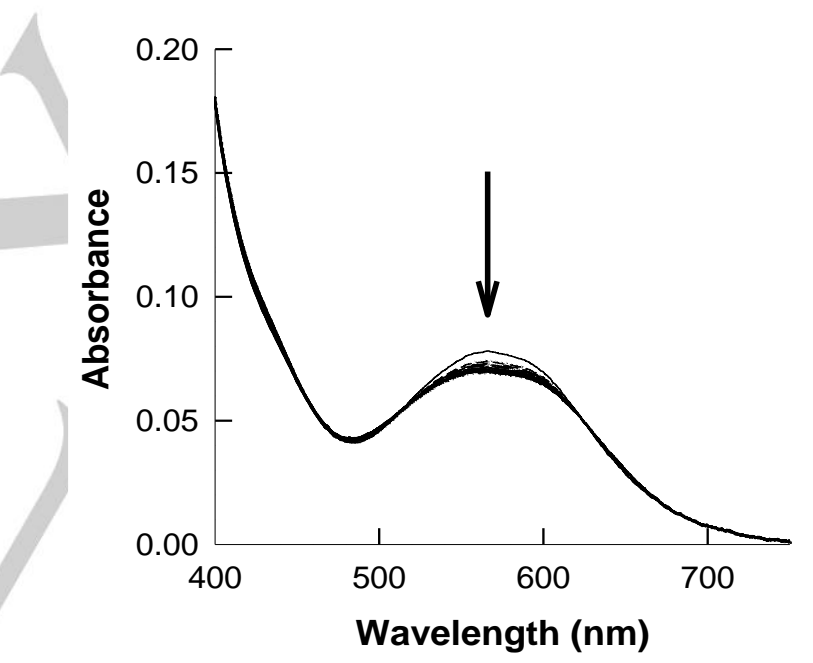

$=-40.0^{\circ} \mathrm{C},\left[1^{+}\right]=1.8 \times 10^{-4} \mathrm{M},\left[\mathrm{Bu}_{4} \mathrm{NOH}\right]=3.3 \times 10^{-4} \mathrm{M}$; time base $\left.=350 \mathrm{~s}\right)$.

The reaction of $1^{+}$with $\mathrm{NaOH}$ and $\mathrm{Bu}_{4} \mathrm{NOH}$ salts was also monitored by ESI mass spectrometry and ${ }^{31} \mathrm{P}\left\{{ }^{1} \mathrm{H}\right\} \mathrm{NMR}$, and the sequential substitution of bromide by hydroxide ligand could be observed by controlling the $\mathrm{OH}^{-}$to cluster ratio. Thus, the sequential substitution is corroborated by the appearance of peaks at $\mathrm{m} / \mathrm{z}=1544,1482$, and 1418 assignable to $\left[\mathrm{W}_{3} \mathrm{~S}_{4} \mathrm{Br}_{2}(\mathrm{OH})(\mathrm{edpp})_{3}\right]^{+}, \quad\left[\mathrm{W}_{3} \mathrm{~S}_{4} \mathrm{Br}(\mathrm{OH})_{2}(\mathrm{edpp})_{3}\right]^{+}, \quad$ and $\left[\mathrm{W}_{3} \mathrm{~S}_{4}(\mathrm{OH})_{3}(\mathrm{edpp})_{3}\right]^{+}$, respectively (Figure 4$)$. In addition, the spectrum in Figure 4 shows signals at $\mathrm{m} / \mathrm{z}=1608$ for $\mathbf{1}^{+}$, at 1500 assignable to an adduct between $\left[\mathrm{W}_{3} \mathrm{~S}_{4} \mathrm{Br}(\mathrm{OH})_{2}(\text { edpp })_{3}\right]^{+}$and an $\mathrm{H}_{2} \mathrm{O}$ molecule, and at 1562 assignable to $\left[\mathrm{W}_{3} \mathrm{~S}_{4} \mathrm{ClBr}_{2}(\mathrm{edpp})_{3}\right]^{+}$, the entering of chloride surely occurring in the instrument during recording of the spectrum. In the same way, the ${ }^{31} \mathrm{P}\left\{{ }^{1} \mathrm{H}\right\}$ NMR spectra recorded after addition of $\mathrm{NaOH}$ show the formation of two reaction intermediates in the conversion of $\mathbf{1}^{+}$to $2^{+}$(Figure 5). While the spectra of the starting cluster and the reaction 

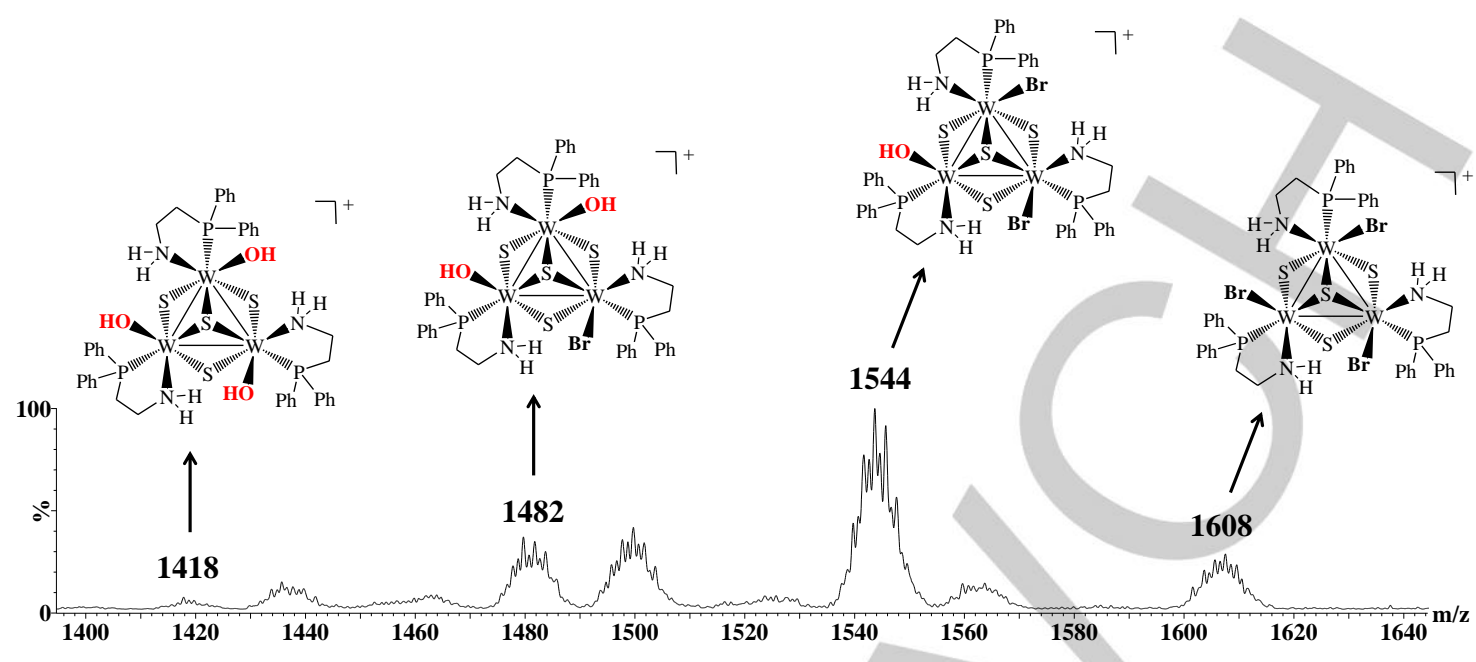

Figure 4. Typical ESI-MS spectrum $\left(\mathrm{U}_{\mathrm{c}}=20 \mathrm{~V}\right)$ showing the mono-, di- and tri-hydroxo clusters formed during the reaction of $\mathbf{1}^{+}\left(\mathrm{c} . \mathrm{a} .3 \times 10^{-4} \mathrm{M}\right)$ with $\mathrm{NaOH}$ (in a $5: 1$ molar ratio of base excess) in an acetonitrile-water solution (10\% water).

product ( $A$ and $D$, respectively) only shows a single signal, the spectra of intermediates $\left[\mathrm{W}_{3} \mathrm{~S}_{4} \mathrm{Br}_{2}(\mathrm{OH})(\mathrm{edpp})_{3}\right]^{+} \quad$ (B) and $\left[\mathrm{W}_{3} \mathrm{~S}_{4} \mathrm{Br}(\mathrm{OH})_{2}(\mathrm{edpp})_{3}\right]^{+}(\mathrm{C})$ show three signals, as expected for a structure where the three edpp ligands are not equivalent. The position of the signals for the different species in included in Table 2.

Table 2. Chemical shifts (in ppm) of the ${ }^{31} \mathrm{P}\left\{{ }^{1} \mathrm{H}\right\}$ signals in $\mathrm{CD}_{3} \mathrm{CN}$ at $25.0^{\circ} \mathrm{C}$ for the species formed in the reaction of $1^{+}$with $\mathrm{OH}^{-}$in acetonitrile solution using two different hydroxides and different amounts of water.

\begin{tabular}{ccccc}
\hline & $\mathrm{W}_{3} \mathrm{Br}_{3}$ & $\mathrm{~W}_{3} \mathrm{Br}_{2}(\mathrm{OH})$ & $\mathrm{W}_{3} \mathrm{Br}(\mathrm{OH})_{2}$ & $\mathrm{~W}_{3}(\mathrm{OH})_{3}$ \\
\hline \multirow{3}{*}{$\mathrm{NaOH}^{\mathrm{a}}$} & & $14.4,14.7$, & $14.3,19.2$, & 19.6 \\
& 15.2 & 18.5 & 19.4 & \\
$\mathrm{Bu}_{4} \mathrm{NOH}^{\mathrm{b}}$ & & $14.4,14.6$, & $13.5,18.3$, & 18.3 \\
& & 18.0 & 18.4 & \\
\hline
\end{tabular}

a Solutions containing $10 \%$ water. ${ }^{\mathrm{b}}$ The solutions containing less than $1 \%$ water. Note that the change in the solvent composition cause small changes in the values of the chemical shifts observed for the reactions with both hydroxides.

The reaction of $\mathbf{1}^{+}$with $\mathrm{Et}_{3} \mathrm{~N}$ in acetonitrile was found to be strongly affected by the presence of water. Thus, in the absence of special care to avoid its presence, stopped-flow, ESI-MS and NMR experiments showed the formation of $2^{+}$and the related mono- and di-hydroxo clusters. Based on these results, the water content was reduced by preparing the solutions inside a glovebox. Note that again the kinetic experiments had to be carried out at low temperature because at $25.0^{\circ} \mathrm{C}$ the first spectrum recorded immediately upon mixing did not correspond to that of the starting cluster. With solutions prepared in this way, the spectral changes recorded at $-20.0^{\circ} \mathrm{C}$ under pseudo-first order conditions of $\mathrm{Et}_{3} \mathrm{~N}$ excess showed that the disappearance of the starting cluster is accompanied by the appearance of a band centered at $420 \mathrm{~nm}$
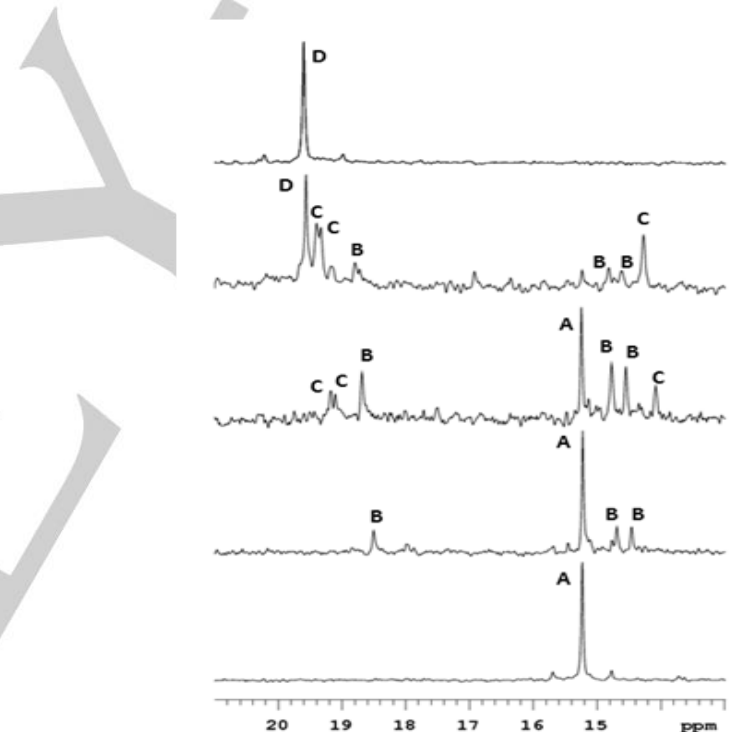

Figure 5 .

NMR spectra showing the conversion of $\mathbf{1}^{+}(A)$ to $\mathbf{2}^{+}(D)$ through intermediate species $\mathrm{B}$ and $\mathrm{C}$. The spectra were obtained through the addition of successive aliquots of a solution of $\mathrm{NaOH}$ in acetonitrile-water ( $10 \%$ water) to a solution of $1^{+}$in acetonitrile- $\mathrm{d}_{3}$ ([cluster $]_{0}=2 \times 10^{-3} \mathrm{M} ;\left[\mathrm{OH}^{-}\right]=2 \times 10^{-4}, 4 \times 10^{-4}, 1.2 \times 10^{-3}$ and $2 \times 10^{-3} \mathrm{M}$, bottom to top). Note that the changes in the solvent composition cause minor shifts in the position of the signals.

changes can be satisfactorily fitted to a kinetic model with a single exponential, yielding the calculated spectra included in Figure S4 and values of $k_{\text {obs }}$ that show a linear dependence with the $\mathrm{Et}_{3} \mathrm{~N}$ concentration (Figure 7, equation 2), with $a=3 \pm 2 \mathrm{~s}^{-1}$ and $b=(8.1$ $\pm 0.4) \times 10^{-2} \mathrm{M}^{-1} \mathrm{~s}^{-1}$ at $-20.0^{\circ} \mathrm{C}$.

$$
k_{\mathrm{obs}}=\mathrm{a}+\mathrm{b} \cdot\left[\mathrm{Et}_{3} \mathrm{~N}\right]
$$
(Figure 6). These 


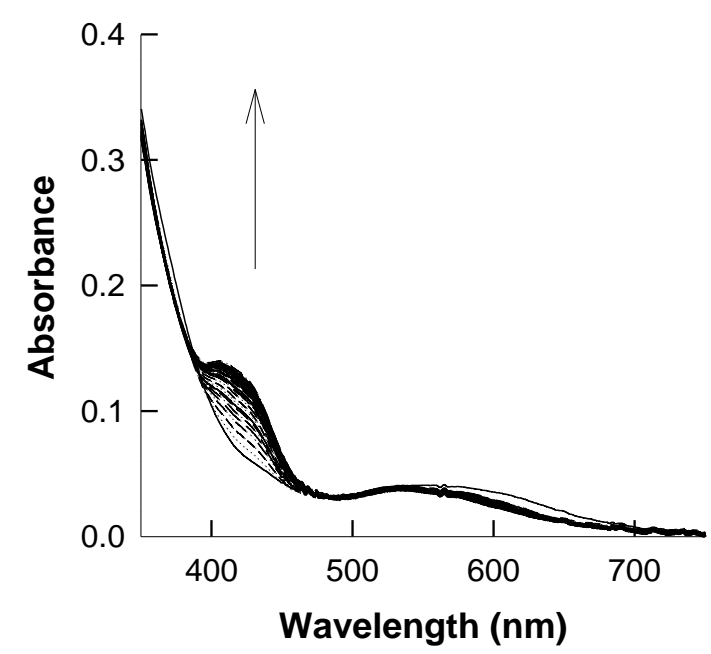

Figure 6. Typical spectral changes for the reaction of $1^{+}$with $\mathrm{Et}_{3} \mathrm{~N}$ in acetonitrile. $\left(\mathrm{T}=-20.0^{\circ} \mathrm{C},\left[1^{+}\right]=2.1 \times 10^{-4} \mathrm{M},\left[\mathrm{Et}_{3} \mathrm{~N}\right]=0.3 \mathrm{M}\right.$; time base $\left.=200 \mathrm{~s}\right)$.

The ESI-MS (Figure 8) spectra of reaction mixtures of $\mathbf{1}^{+}$and $\mathrm{Et}_{3} \mathrm{~N}$ in acetonitrile show a prominent peak centered at $\mathrm{m} / \mathrm{z}=1465$ that can be attributed to the formation of $\left[\mathrm{W}_{3} \mathrm{~S}_{4}(\mathrm{edpp}-\mathrm{H})_{3}\left(\mathrm{Et}_{3} \mathrm{~N}\right)\right]^{+}$ (edpp- $\mathrm{H}=$ deprotonated (2-aminoethyl) diphenylphosphine) on the basis of the $\mathrm{m} / \mathrm{z}$ value and its characteristic isotopic pattern. In addition, signals centered at $\mathrm{m} / \mathrm{z}=1405,1446,1486$ and 1526 assignable to $\left[\mathrm{W}_{3} \mathrm{~S}_{4}(\mathrm{edpp}-\mathrm{H})_{3}\left(\mathrm{CH}_{3} \mathrm{CN}\right)\right]^{+},\left[\mathrm{W}_{3} \mathrm{~S}_{4} \mathrm{Br}(\mathrm{edpp})(\mathrm{edpp}-\right.$ $\left.\mathrm{H})_{2}\right]^{+}, \quad\left[\mathrm{W}_{3} \mathrm{~S}_{4} \mathrm{Br}(\mathrm{edpp})(\mathrm{edpp}-\mathrm{H})_{2}\left(\mathrm{CH}_{3} \mathrm{CN}\right)\right]^{+} \quad$ and $\left[\mathrm{W}_{3} \mathrm{~S}_{4} \mathrm{Br}_{2}(\text { edpp })_{2}(\text { edpp- } \mathrm{H})\right]^{+}$, respectively, are also observed. The sensitivity of the reaction to the presence of traces of water is confirmed by the appearance even under those conditions of small peaks for the mono-, di- and trihydroxide species $(\mathrm{m} / \mathrm{z}=$ 1544,1482 and 1418 ), and a signal at $m / z=1503$ assignable to $\left[\mathrm{W}_{3} \mathrm{~S}_{4} \mathrm{Br}(\mathrm{OH})(\mathrm{edpp})_{2}(\mathrm{edpp}-\mathrm{H})\left(\mathrm{CH}_{3} \mathrm{CN}\right)\right]^{+}$. All these different species with two, one or no $\mathrm{Br}^{-}$bonded are reasonably expected to be formed if it is considered that using an excess of triethylamine leads to substitution of $\mathrm{Br}^{-}$by the amine, which dissociates easily under the ESI-MS conditions. Coordination of the solvent (acetonitrile) is also likely to be occurring. However, the most relevant observation is perhaps the occurrence of products resulting from deprotonation of the edpp ligands, which suggests that $\mathrm{Et}_{3} \mathrm{~N}$ is also acting as a base, abstracting a proton from the $\mathrm{NH}_{2}$ group of edpp.

On the other hand, the ${ }^{31} \mathrm{P}\left\{{ }^{1} \mathrm{H}\right\} \mathrm{NMR}$ spectra of samples prepared by adding an excess of $\mathrm{Et}_{3} \mathrm{~N}$ to $1^{+}$show the appearance of a broad signal at $17.8 \mathrm{ppm}$ (Figure S5), which coexists with the starting compound. With this information, the rate law in equation (2) can be interpreted in terms of a reversible process, with $b$ corresponding to the rate constant for the direct reaction and $a$ to the rate constant for the reverse reaction. From the values of $a$ and $b$, and equilibrium constant close to $27 \mathrm{M}^{-1}$ at $-20.0^{\circ} \mathrm{C}$ can be estimated. Cooling the solution causes additional broadening of the signal for the reaction product, thus revealing the occurrence of a dynamic process rapid in the NMR timescale.
These observations are in agreement with the ESI-MS results and can be interpreted in terms of rapid proton exchange between $\mathrm{Et}_{3} \mathrm{~N}$ and the cluster, although the slow kinetics suggests that it must be accompanied by some other process, probably bromide dissociation based on the ESI-MS results. When the solution is aged for several days, besides the signal at $17.8 \mathrm{ppm}$, the NMR spectra also show a series of less intense signals between 28 and $40 \mathrm{ppm}$, which correspond to decomposition products formed in subsequent reactions that were not explored in detail.

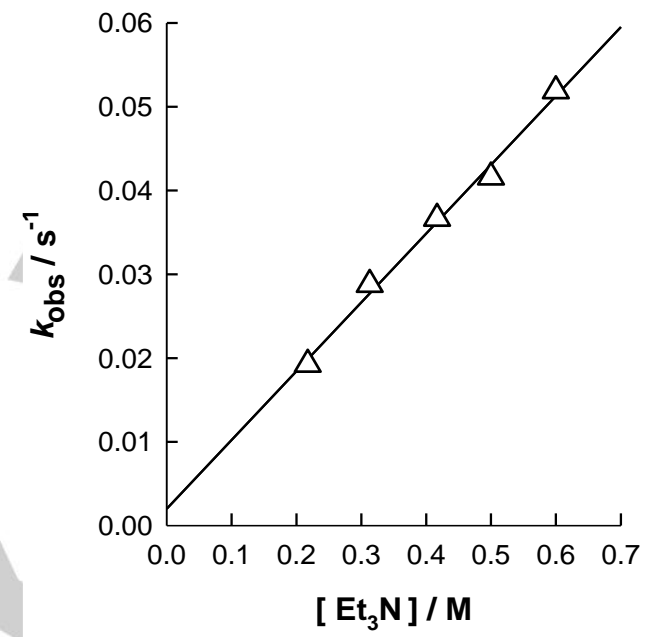

Figure 7. For the reaction of $1^{+}$with an excess of $\mathrm{Et}_{3} \mathrm{~N}$ in acetonitrile at $-20.0^{\circ} \mathrm{C}$ plot of the dependence of $k_{0}$ obs with [Et $\left.{ }_{3} \mathrm{~N}\right]$. The solid line corresponds to the fit of data using eq. (2).

\section{DFT studies}

The results in the previous sections clearly show that $1^{+}$reacts with $\mathrm{OH}^{-}$and $\mathrm{Et}_{3} \mathrm{~N}$ in different ways. This observation is especially interesting given that, a priori, both reagents can behave both as base and coordinating ligands to $\mathrm{W}$. Although the negative charge of $\mathrm{OH}^{-}$is expected to favor its coordination, the results obtained for $\mathrm{Et}_{3} \mathrm{~N}$ indicate that this amine is also able to cause the release of coordinated bromides. DFT calculations have been used to get further insights into the reactivity of $\mathbf{1}^{+}$towards both reagents (see computational details). For simplicity, the computations focused on the processes taking place at a single metal centre, an approach that has proven useful to study the reactivity of cuboidal clusters in the past. ${ }^{7,10}, \underline{12}, \underline{17}$ The computations started by optimizing the hypothetical species resulting from the coordination of $\mathrm{OH}^{-}$and $\mathrm{Et}_{3} \mathrm{~N}$ to the species resulting from dissociation of $\mathrm{Br}^{-}$in $\mathbf{1}^{+}$, i.e. $\left[\mathrm{W}_{3} \mathrm{~S}_{4} \mathrm{Br}_{2}(\text { edpp })_{3}\right]^{2+}$. However, whereas the structure of $\left[\mathrm{W}_{3} \mathrm{~S}_{4}(\mathrm{OH}) \mathrm{Br}_{2}(\text { edpp })_{3}\right]^{+}$could be easily optimized, all attempts to optimize $\left[\mathrm{W}_{3} \mathrm{~S}_{4}\left(\mathrm{Et}_{3} \mathrm{~N}\right) \mathrm{Br}_{2}(\mathrm{edpp})_{3}\right]^{2+}$ by placing the $\mathrm{Et}_{3} \mathrm{~N}$ ligand in the proximities of the vacant coordination site formed by the dissociative loss of $\mathrm{Br}^{-}$were unsuccessful. Instead, the resulting geometry still featured the vacant site at the metal centre, with the $\mathrm{Et}_{3} \mathrm{~N}$ group $\mathrm{H}$-bonded to the amine of the edpp ligand 


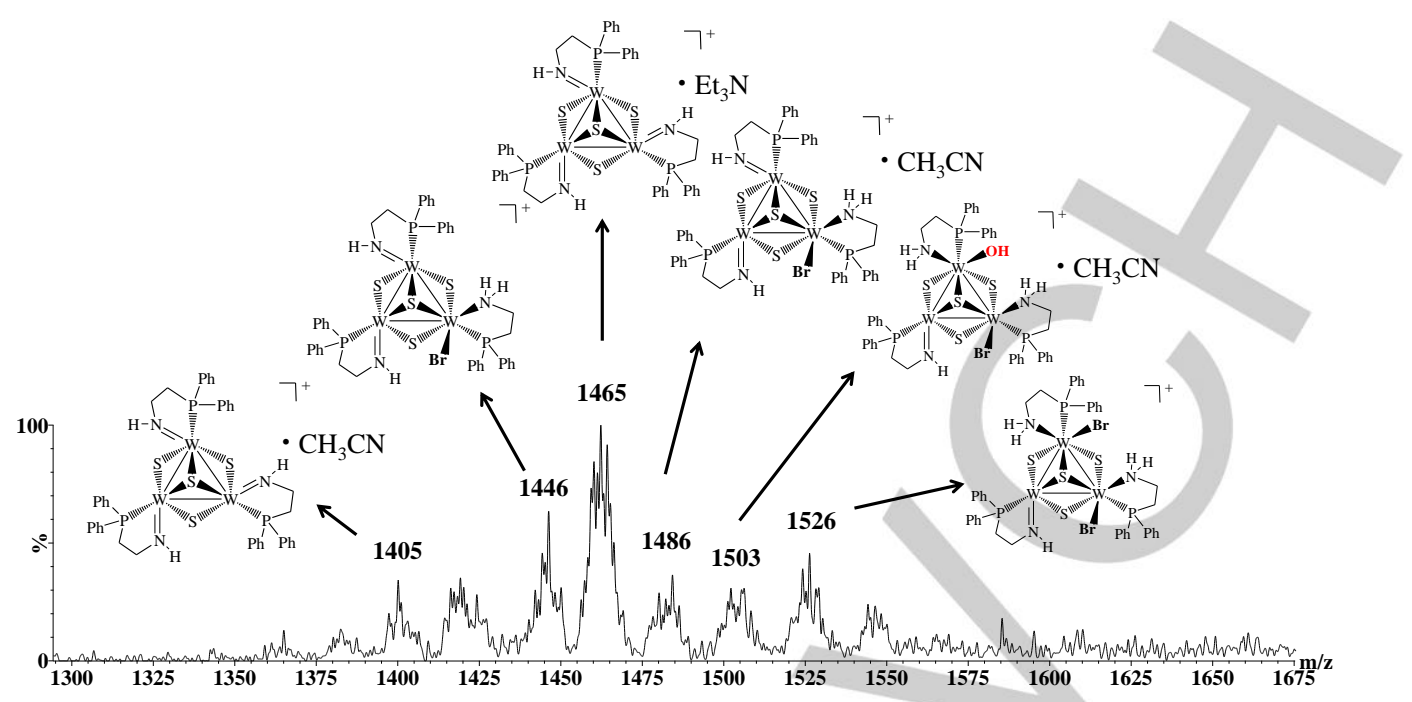

Figure 8. ESI-MS spectrum $\left(\mathrm{U}_{\mathrm{c}}=20 \mathrm{~V}\right)$ showing the products formed in the reaction between $1^{+}$(c.a. $\left.3 \times 10^{-4} \mathrm{M}\right)$ and Et $\mathrm{N}_{3} \mathrm{~N}$ (in a $5: 1$ molar ratio of base excess) in acetonitrile solution.

$\left(d\left(E t_{3} N \cdots H N\right)=1.74 \AA\right.$, see Figure 9). This interaction leads to a small increase in the $\mathrm{N}-\mathrm{H}$ distance within the edpp ligand up to $1.10 \AA$ (cf. $1.04 \AA$ in $1^{+}$), all in all showing the behavior of $\mathrm{Et}_{3} \mathrm{~N}$ as a base.

Once having concluded that $\mathrm{Et}_{3} \mathrm{~N}$ is not likely to behave as a ligand, the acid-base behavior of both $\left[\mathrm{W}_{3} \mathrm{~S}_{4} \mathrm{Br}_{3}(\text { edpp })_{3}\right]^{+}$and $\mathrm{Et}_{3} \mathrm{NH}^{+}$was evaluated by computing their $\mathrm{p} K_{\mathrm{a}}$ values. It is worth noting that the $\mathrm{p} K_{\mathrm{a}}$ value of 17.0 obtained for $\mathrm{Et}_{3} \mathrm{NH}^{+}$(see Table 3 ) is in good agreement with the experimental value of $18.46,49$ thus supporting the use of these data to draw qualitative conclusions. Interestingly, the $\mathrm{p} K_{\mathrm{a}}$ computed for $\mathbf{1}^{+}$(18.5) indicates that this cluster is only slightly less acidic than $\mathrm{Et}_{3} \mathrm{NH}^{+}$, and therefore cluster deprotonation is likely to take place in the presence of $\mathrm{Et}_{3} \mathrm{~N}$ excess. Table 3 also includes the $\mathrm{p} K_{\mathrm{a}}$ values computed for the deprotonation of the edpp ligand at species resulting from the substitution of the $\mathrm{Br}^{-}$ligand by an acetonitrile solvent molecule $\left(p K_{a}=13.0\right)$ and $\mathrm{OH}^{-}\left(p K_{a}=24.0\right)$. These values clearly show that the nature of the monodentate ligand has a profound impact on the acid-base properties of the neighboring edpp ligand. On the basis of the data in Table 3, the most likely process occurring in the presence of a combination of $\mathrm{Et}_{3} \mathrm{~N}$ and traces of $\mathrm{H}_{2} \mathrm{O}$ is the formal substitution of $\mathrm{Br}^{-}$ligands by $\mathrm{OH}^{-}$, with no ligand deprotonation taking place due to the significantly less acidic character of $\left[\mathrm{W}_{3} \mathrm{~S}_{4} \mathrm{Br}_{2}(\mathrm{OH})(\mathrm{edpp})_{3}\right]^{+}$with respect to $\mathrm{Et}_{3} \mathrm{NH}^{+}$. Accordingly, the process represented in Eq. 3 shows a computed reaction free energy of $-3.5 \mathrm{kcal} \mathrm{mol}^{-1}$.

$$
\begin{aligned}
& \mathbf{1}^{+}+\mathrm{Et}_{3} \mathrm{~N}+\mathrm{H}_{2} \mathrm{O} \rightarrow \\
& {\left[\mathrm{W}_{3} \mathrm{~S}_{4} \mathrm{Br}_{2}(\mathrm{OH})(\mathrm{edpp})_{3}\right]+\mathrm{Et}_{3} \mathrm{~N}^{+} \ldots \mathrm{Br}^{;} ; \Delta G_{\mathrm{r}}=-3.5 \mathrm{kcal} \mathrm{mol}^{-1}}
\end{aligned}
$$$$
\mathbf{1}^{+}+\mathrm{Et}_{3} \mathrm{~N} \rightarrow
$$

$\left[\mathrm{W}_{3} \mathrm{~S}_{4} \mathrm{Br}_{3}(\text { edpp })_{2}(\right.$ edpp-H) $]+\mathrm{HEt}_{3} \mathrm{~N}^{+} ; \quad \Delta \mathrm{G}_{\mathrm{r}}=+3.4 \mathrm{kcal} \mathrm{mol}^{-1}$
On the contrary, the reaction of $\mathbf{1}^{+}$with an excess of $\mathrm{Et}_{3} \mathrm{~N}$ in the absence of $\mathrm{H}_{2} \mathrm{O}$ is expected to result in the formation of $\left[\mathrm{W}_{3} \mathrm{~S}_{4} \mathrm{Br}_{3}(\mathrm{edpp})_{2}(\mathrm{edpp}-\mathrm{H})\right]$. Although, in agreement with their computed $\mathrm{p} K_{\mathrm{a}}$ values, the process in Eq. 4 has a reaction free energy of $+3.4 \mathrm{kcal} \mathrm{mol}^{-1}$, a large excess of amine is expected to shift the equilibrium towards deprotonation. This conclusion is in agreement with the experimental findings, in particular the preponderance of deprotonated species in the ESI-MS spectra of reaction mixtures with $\mathrm{Et}_{3} \mathrm{~N}$ excess, and the absence of $\mathrm{Et}_{3} \mathrm{~N}$ in most signals except the one at $\mathrm{m} / \mathrm{z}=1465$, which probably corresponds to an adduct formed in the mass spectrometer. Interestingly, proton exchange between edpp ligands and $\mathrm{Et}_{3} \mathrm{~N}$ is also expected to be fast, which would account for the broadening of the phosphorus NMR signals. Nevertheless, the kinetics of reaction is slower than expected for a simple proton exchange thus suggesting that proton exchange must be accompanied by some other process. The ESI-MS spectra suggest that edpp deprotonation is accompanied by $\mathrm{Br}^{-}$release, and thus the reaction free energies for $\mathrm{Br}^{-}$dissociation both at $1^{+}$(Eq. 5) and $\left[\mathrm{W}_{3} \mathrm{~S}_{4} \mathrm{Br}_{3}(\mathrm{edpp})_{2}(\mathrm{edpp}-\mathrm{H})\right]$ (Eq. 6) were computed.

Inspection of the $\mathrm{W}-\mathrm{Br}$ distances in $\left[\mathrm{W}_{3} \mathrm{~S}_{4} \mathrm{Br}_{3}(\text { edpp })_{2}(\right.$ edpp- $\left.\mathrm{H})\right]$ shows that the distance is longer for the $\mathrm{W}-\mathrm{Br}$ bond with the metal center featuring the deprotonated edpp ( $2.76 \AA$ 淀 2.73 and 2.65 $\AA$ ), thus making bromide dissociation more favorable than in unreacted $\mathbf{1}^{+}$(the three $\mathrm{W}-\mathrm{Br}$ distances are $2.66 \AA$ in $\mathbf{1}^{+}$). Although both processes are thermodynamically unfavoured, the values show that the energy required for dissociating bromide at $\left[\mathrm{W}_{3} \mathrm{~S}_{4} \mathrm{Br}_{3}(\mathrm{edpp})_{2}(\mathrm{edpp}-\mathrm{H})\right]$ (Eq. 6) is significantly lower than that for the same process at unmodified $\mathbf{1}^{+}$(Eq. 5). Note that the energy cost can be partially compensated by ion pairing between $\mathrm{HEt}_{3} \mathrm{~N}^{+}$and $\mathrm{Br}^{-}$, and also by solvent (MeCN) coordination at the newly generated vacant sites, and thus, all in all the data indicate that $\mathrm{Br}^{-}$dissociation is more likely to occur upon edpp deprotonation. The global process can be represented by Eq. 7, which features a reaction free energy of - 


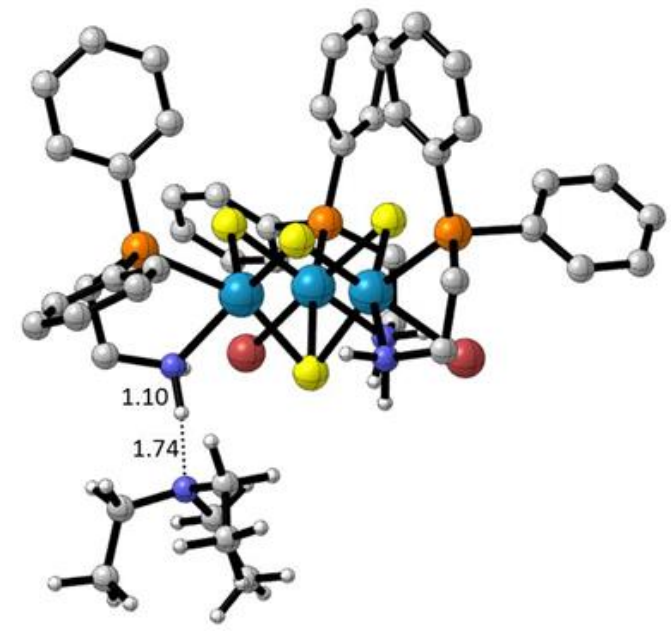

Figure 9. Optimized structure of $\left[\mathrm{W}_{3} \mathrm{~S}_{4} \mathrm{Br}_{2}(\mathrm{edpp})_{3}\right]^{2+} \ldots \mathrm{Et} \mathrm{t}_{3} \mathrm{~N}$. For simplicity, $\mathrm{H}$ atoms bound to $\mathrm{C}$ at edpp ligands have been omitted. Distances are given in $\AA$.

Table 3. Computed $p K_{a}$ values.

\begin{tabular}{cc}
\hline Species & $\mathrm{p} K_{\mathrm{a}}$ \\
\hline $\mathrm{Et}_{3} \mathrm{NH}^{+}$ & 17.0 \\
{$\left[\mathrm{~W}_{3} \mathrm{~S}_{4} \mathrm{Br}_{3}(\mathrm{edpp})_{3}\right]^{+}$} & 18.5 \\
{$\left[\mathrm{~W}_{3} \mathrm{~S}_{4} \mathrm{Br}_{2}(\mathrm{OH})(\mathrm{edpp})_{3}\right]^{+}$} & 24.0 \\
{$\left[\mathrm{~W}_{3} \mathrm{~S}_{4} \mathrm{Br}_{2}(\mathrm{MeCN})(\mathrm{edpp})_{3}\right]^{2+}$} & 13.0 \\
$\mathrm{H}_{2} \mathrm{O}$ & 66.2 \\
$\mathrm{H}_{3} \mathrm{O}^{+}$ & -14.8 \\
\hline
\end{tabular}

$0.4 \mathrm{kcal} \mathrm{mol}^{-1}$ (at $25.0^{\circ} \mathrm{C}$ ), a value that matches well with the kinetic results indicating that it takes place under reversible conditions with an estimated equilibrium constant of $27 \mathrm{M}^{-1}$ at $20.0{ }^{\circ} \mathrm{C}$. In fact, the presence of acetonitrile in several of the signals in the mass spectra would support this interpretation, whereas the appearance of signals without acetonitrile or any other ligand could be a consequence of its dissociation during recording of the spectra.

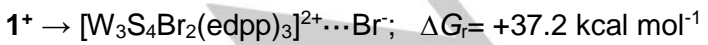

$\left[\mathrm{W}_{3} \mathrm{~S}_{4} \mathrm{Br}_{3}(\text { edpp })_{2}(\right.$ edpp- $\left.\mathrm{H})\right] \rightarrow$

$\left[\mathrm{W}_{3} \mathrm{~S}_{4} \mathrm{Br}_{2}(\text { edpp })_{2}(\mathrm{edpp}-\mathrm{H})\right]^{+} \ldots \mathrm{Br} ; \quad \Delta \mathrm{G}_{\mathrm{r}}=+23.2 \mathrm{kcal} \mathrm{mol}^{-1}$
$\mathbf{1}^{+}+\mathrm{Et}_{3} \mathrm{~N}+\mathrm{CH}_{3} \mathrm{CN} \rightarrow$

$\left[\mathrm{W}_{3} \mathrm{~S}_{4} \mathrm{Br}_{2}\left(\mathrm{CH}_{3} \mathrm{CN}\right)(\text { edpp })_{2}(\text { edpp }-\mathrm{H})\right]^{+}+\mathrm{Et}_{3} \mathrm{~N}^{+} \ldots \mathrm{Br} ; \Delta \mathrm{G}_{\mathrm{r}}=-0.4 \mathrm{kcal}$ $\mathrm{mol}^{-1}$

At this point, some comments are necessary regarding the reaction of $1^{+}$with $\mathrm{OH}^{-}$, which is experimentally found to be much faster than those with other anionic ligands. 17 The computed $p K_{a}$ of water (see Table 3 ) indicates that $\mathrm{OH}^{-}$is also able to abstract a proton from a coordinated edpp ligand in $\mathbf{1}^{+}$(Eq. 8), with the resulting species $\left[\mathrm{W}_{3} \mathrm{~S}_{4} \mathrm{Br}_{3}(\text { edpp })_{2}(\right.$ edpp-H)] being prone to $\mathrm{Br}$ dissociation (Eq. 6). However, unlike $\mathrm{Et}_{3} \mathrm{~N}$, an $\mathrm{OH}^{-}$anion can occupy the vacant coordination site to form the corresponding hydroxo cluster (Eq. 9), thus allowing for completion of the $\mathrm{Br}^{-}$by $\mathrm{OH}^{-}$substitution through a conjugate-base mechanism (Eqs. 8, 6 and 9) similar to that well established for base hydrolysis of octahedral amine complexes of $\mathrm{Co}$ (III) and other metal ions complexes. $\frac{50}{}$

Interestingly, based on the $\mathrm{p} K_{\mathrm{a}}$ values in Table 3 , $\left[\mathrm{W}_{3} \mathrm{~S}_{4} \mathrm{Br}_{2}(\mathrm{OH})(\mathrm{edpp})_{3}\right]^{+}$should also be deprotonated in the presence of $\mathrm{OH}^{-}$excess (Eq. 10), and indeed, the ESI-MS of the reaction mixture of $1^{+}$and a higher excess of $\mathrm{NaOH}$ (molar ratio $1^{+} / \mathrm{NaOH}$ of $1: 25$ ) shows, in addition to the peak associated with the tri-substituted $\left[\mathrm{W}_{3} \mathrm{~S}_{4}(\mathrm{OH})_{3}(\mathrm{edpp})_{3}\right]^{+}(\mathrm{m} / \mathrm{z}$ 1418) cation, three peaks at $\mathrm{m} / \mathrm{z} 1400,1382$ and 1364 that can be assigned to the unsaturated cations $\quad\left[\mathrm{W}_{3} \mathrm{~S}_{4}(\mathrm{OH})_{2}(\text { edpp })_{2}(\text { edpp- } \mathrm{H})\right]^{+}$, $\left[\mathrm{W}_{3} \mathrm{~S}_{4}(\mathrm{OH})(\mathrm{edpp})(\mathrm{edpp}-\mathrm{H})_{2}\right]^{+}$and $\left[\mathrm{W}_{3} \mathrm{~S}_{4}(\text { edpp- } \mathrm{H})_{3}\right]^{+}$, respectively (see figure S6). Such an observation is in agreement with computations and indicate that in the presence of an excess of $\mathrm{OH}^{-}$the reaction product is indeed $\left[\mathrm{W}_{3} \mathrm{~S}_{4} \mathrm{Br}_{2}(\mathrm{OH})(\text { edpp })_{2}(\right.$ edpp- $\left.\mathrm{H})\right]$ together with related species resulting from the reaction at the other metal sites.

$\mathbf{1}^{+}+\mathrm{OH}^{-} \rightarrow\left[\mathrm{W}_{3} \mathrm{~S}_{4} \mathrm{Br}_{3}(\text { edpp })_{2}(\right.$ edpp $\left.-\mathrm{H})\right]+\mathrm{H}_{2} \mathrm{O} ; \quad \Delta G_{\mathrm{r}}=-62.7 \mathrm{kcal}$ $\mathrm{mol}^{-1}$

$\left[\mathrm{W}_{3} \mathrm{~S}_{4} \mathrm{Br}_{2} \text { (edpp) }\right)_{2}($ edpp-H) $] \cdots \mathrm{Br}^{-}+\mathrm{H}_{2} \mathrm{O} \rightarrow$

$\left[\mathrm{W}_{3} \mathrm{~S}_{4} \mathrm{Br}_{2}(\mathrm{OH})(\mathrm{edpp})_{3}\right] \cdots \mathrm{Br}^{-} ; \quad \Delta \mathrm{G}_{\mathrm{r}}=-34.0 \mathrm{kcal} \mathrm{mol}^{-1}$

$\left[\mathrm{W}_{3} \mathrm{~S}_{4} \mathrm{Br}_{2}(\mathrm{OH})(\mathrm{edpp})_{3}\right]^{+}+\mathrm{OH}^{-} \rightarrow$

$\left[\mathrm{W}_{3} \mathrm{~S}_{4} \mathrm{Br}_{2}(\mathrm{OH})(\mathrm{edpp})_{2}(\right.$ edpp $\left.-\mathrm{H})\right]+\mathrm{H}_{2} \mathrm{O} ; \quad \Delta \mathrm{G}_{\mathrm{r}}=-55.8 \mathrm{kcal} \mathrm{mol}^{-1}$

\section{Conclusions}

The results in the present work clearly demonstrate that $\mathbf{1}^{+}$shows a different behaviour against $\mathrm{OH}^{-}$and $\mathrm{Et}_{3} \mathrm{~N}$. Whereas a trihydroxo cluster $2^{+}$is formed in the presence of low concentrations of $\mathrm{OH}^{-}$, much larger concentrations are required in the case of $\mathrm{Et}_{3} \mathrm{~N}$ to cause conversion of the starting cluster. Although in the latter case the reaction product could not be isolated, the characterization by NMR and ESI-MS as well as the DFT results, clearly indicate that $\mathrm{Et}_{3} \mathrm{~N}$ does not coordinate to the metal centres but it simply acts by taking a proton from a coordinated edpp ligand, a process which is accompanied by $\mathrm{Br}^{-}$dissociation. Nevertheless, the results also show that deprotonation of edpp 
also plays an active role in the reaction with $\mathrm{OH}^{-}$by providing a reaction pathway involving dissociative loss of the leaving $\mathrm{Br}^{-}$that becomes easier than in the starting complex.

\section{Experimental Section}

\section{General remarks}

Elemental analyses were carried out on a EuroEA3000 Eurovector Analyser. Electrospray mass spectra were recorded with a Quattro LC (quadrupole-hexapole-quadrupole) mass spectrometer with an orthogonal Z-spray electrospray interface (Micromass, Manchester, UK). The cone voltage was set at $20 \mathrm{~V}$ unless otherwise stated using $\mathrm{CH}_{3} \mathrm{CN}$ as the mobile phase solvent. Sample solutions have been infused via syringe pump directly connected to the ESI source at a flow rate of $10 \mu \mathrm{L} / \mathrm{min}$ and a capillary voltage of $3.5 \mathrm{kV}$ was used in the positive scan mode. Nitrogen was employed as drying and nebulising gas. Isotope experimental patterns were compared with theoretical patterns obtained using the MassLynx 4.0 program. $\underline{23}$ To characterize the substitution products, standard highresolution NMR spectroscopy experiments, such as $1 \mathrm{D}{ }^{1} \mathrm{H},{ }^{31} \mathrm{P}$ NMR and 2D g-COSY and g-HSQC were recorded on Agilent 400 and $500 \mathrm{MHz}$ at $-35.0{ }^{\circ} \mathrm{C}$ and $25.0^{\circ} \mathrm{C}$, using $\mathrm{CD}_{3} \mathrm{CN}$ as solvents and referenced to $\mathrm{CFCl}_{3}$ and $85 \% \mathrm{H}_{3} \mathrm{PO}_{4}$, respectively.

\section{Synthesis}

$\left[\mathrm{W}_{3} \mathrm{~S}_{4} \mathrm{Br}_{3}(\text { edpp })_{3}\right] \mathrm{Br}(\mathbf{1}(\mathrm{Br}))$ has been prepared following the literature procedure. 17 Replacement of the $\mathrm{Br}$ counter-ion was carried out by addition of an excess of $\mathrm{Na}\left(\mathrm{BPh}_{4}\right)$ to methanol solutions of $1(\mathrm{Br})$, resulting in precipitation of the desired tetraphenylborate salts of the $1^{+}$trinuclear cation. The remaining reactants were obtained from commercial sources and used as received.

$\left[\mathrm{W}_{3} \mathrm{~S}_{4}(\mathrm{OH})_{3}(\mathrm{edpp})_{3}\right] \mathrm{BPh}_{4} \quad\left(2\left(\mathrm{BPh}_{4}\right)\right): \quad \mathrm{A}$ blue solution of $\left[\mathrm{W}_{3} \mathrm{~S}_{4} \mathrm{Br}_{3}(\mathrm{edpp})_{3}\right] \mathrm{BPh}_{4}\left(\mathbf{1}\left(\mathrm{BPh}_{4}\right)\right)(0.050 \mathrm{~g}, 0.026 \mathrm{mmol})$ in $\mathrm{CH}_{3} \mathrm{CN} / \mathrm{H}_{2} \mathrm{O}$ $(2: 1,30 \mathrm{~mL})$ was treated dropwise with an aqueous solution of $0.1 \mathrm{M}$ $\mathrm{NaOH}(1.43 \mathrm{~mL}, 0.143 \mathrm{mmol})$ and the mixture was stirred at room temperature for $4 \mathrm{~h}$. A purple coloured suspension resulted after removing part of the solvent (ca $20 \mathrm{~mL}$ ) under reduced pressure. After filtration, the solid was subsequently washed with isopropanol: water (1:1) and

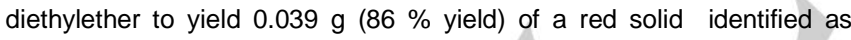
$\left(2\left(\mathrm{BPh}_{4}\right)\right)$.

${ }^{31} \mathrm{P}\left\{{ }^{1} \mathrm{H}\right\} \operatorname{NMR}\left(\mathrm{CD}_{3} \mathrm{CN}, 121 \mathrm{MHz}\right) \quad \delta=19.60(3 \mathrm{P}, \mathrm{s}) . \mathrm{IR}\left(\mathrm{cm}^{-1}, \mathrm{KBr}\right): 1440$ (s), 1105 (s) 1137 (s), 962 (w), 825 (w), 690 (s) 525 (s), $421\left(w, W-\mu_{3} S\right)$ UV-Vis $\left(\mathrm{CH}_{3} \mathrm{CN}\right)$ : $\lambda_{\max }(\varepsilon) 362$ (8206), 385 (6507), $632 \mathrm{~nm}\left(350 \mathrm{M}^{-1} \mathrm{~cm}^{-1}\right)$. ESI-MS $\left(\mathrm{CH}_{3} \mathrm{CN}\right) \mathrm{m} / \mathrm{z}: 1418\left[\mathrm{M}^{+}\right.$. Anal. Calc. $\mathrm{W}_{3} \mathrm{O}_{3} \mathrm{~S}_{4} \mathrm{P}_{3} \mathrm{~N}_{3} \mathrm{C}_{66} \mathrm{H} \mathrm{H}_{71} \mathrm{~B}(\%)$ : C, $45.6 ; \mathrm{H}, 4.1 ; \mathrm{N}, 2.4 \operatorname{Exp}(\%): \mathrm{C}, 45.9 ; \mathrm{H}, 4.3 ; \mathrm{N}, 2.8 \%$.

\section{X-ray data collection and structure refinement}

Crystals of the tetraphenylborate salt of $\mathbf{2}^{+}$suitable for X-ray studies were grown by slow vapor diffusion of diethyl ether into a sample solution in $\mathrm{CH}_{2} \mathrm{Cl}_{2}$. X-ray diffraction experiments were carried out on a Agilent Supernova diffractometer equipped with an Atlas CCD detector using $\mathrm{Cu}$ Ka radiation $(\lambda=1.54184 \AA)$. No instrument or crystal instabilities were observed during data collection. Absorption corrections based on the multiscan method were applied. ${ }^{24-25}$ The structure was solved by direct methods in SHELXS-97 and refined by the full-matrix method based on $\mathrm{F}^{2}$ with the program SHELXL-97 using the OLEX software package. $\frac{26-27}{27}$ Crystal data for $2\left(\mathrm{BPh}_{4}\right) \cdot\left(\mathrm{CH}_{2} \mathrm{Cl}_{2}\right): \mathrm{C}_{67} \mathrm{H}_{72.85} \mathrm{BBr}_{0.15} \mathrm{Cl}_{2} \mathrm{~N}_{3} \mathrm{O}_{2.85} \mathrm{P}_{3} \mathrm{~S}_{4} \mathrm{~W}_{3}, \quad M=$
1832.12, monoclinic, space group $P 21 / n, a=14.3856(3) \AA, b=16.0827$ (3) $\AA, c=29.9751(6) \AA, \alpha=90^{\circ}, \beta=99.8558(19)^{\circ}, \gamma=90^{\circ}, V=6832.7(2)$ $\AA^{3}, T=200.00(14) \mathrm{K}, Z=4, \mu(\mathrm{Cu} \mathrm{Ka}) 12.128 \mathrm{~mm}^{-1}$. Reflections collected/unique $=58393 / 12060\left(R_{\text {int }}=0.0574\right)$. Final refinement converged with $R_{1}=0.0884$ and $R_{2}=0.1521$ for all reflections, GOF = 1.135, $\mathrm{max} / \mathrm{min}$ residual electron density $3.46 /-1.72 \mathrm{e} \cdot \AA^{-3}$. In the final difference Fourier map the highest residual density peak is located, at 0.9 $\AA$, near the $\mathrm{W}(3)$ atom. One of the outer positions on the $\mathrm{W}(3)$ atom was refined as $\mathrm{O} / \mathrm{Br}$ with $=0.85 / 0.15$ partial occupancies. Two other crystals were examined and an identical $\mathrm{O} / \mathrm{Br}$ disorder was observed in this site. Apparently crystallization of the $2^{+}$cation occurs preferentially in the presence of small traces of the partially substituted $\left[\mathrm{W}_{3} \mathrm{~S}_{4} \mathrm{Br}(\mathrm{OH})_{2}(\text { edpp })_{3}\right]^{+}$cluster cation, not detected by routine spectroscopic and spectrometric techniques. After refinement of the cluster and cation atoms, a $\mathrm{CH}_{2} \mathrm{Cl}_{2}$ solvent molecule was located in the difference Fourier map. Anisotropic displacement parameters were refined for all non- $\mathrm{H}$ atoms. The hydrogen atoms bonded to carbon were included at their idealized positions and refined as riders with isotropic displacement parameters assigned as 1.2 times the $U_{\text {eq }}$ value of the corresponding bonding partner. The hydrogen atoms bonded to oxygen were also treated in a similar way with isotropic displacement parameters assigned as 1.5 times the $U_{\text {eq }}$ value of the corresponding bonding partner. The structural figures were drawn using the Diamond visual crystal structure information system software. $\underline{28}$

\section{Kinetic experiments}

The kinetics experiments were carried out with an Applied Photophysics SX-18MV stopped-flow spectrometer provided with a PDA1 photodiode array (PDA) detector and a Biologic SFM-4000 cryo-stopped-flow spectrometer. The experiments were carried out between $25.0^{\circ} \mathrm{C}$ and $-40.0^{\circ} \mathrm{C}$. The reactions of $\left[\mathrm{W}_{3} \mathrm{~S}_{4} \mathrm{Br}_{3}(\mathrm{edpp})_{3}\right] \mathrm{Br}$ cluster $(\mathbf{1}(\mathrm{Br}))$ ([cluster] $=$ $\left.1.8 \times 10^{-4}-2 \times 10^{-3} \mathrm{M}\right)$ with the different reagents $\left(\mathrm{Et}_{3} \mathrm{~N}, \mathrm{NaOH}\right.$ and $\left.\mathrm{Bu}_{4} \mathrm{NOH}\right)$ have been studied using acetonitrile or acetonitrile-water mixture as solvent using the bases in a concentration range between $3.4 \times 10^{-4}-0.6$ $\mathrm{M}$; i.e. from stoichiometric conditions to pseudo first order conditions of base excess. Measurements with anionic salts were performed in the presence of $0.05 \mathrm{M}\left(\mathrm{Bu}_{4} \mathrm{NClO}_{4}\right)$ supporting electrolyte. In all cases the spectral changes were measured over a wide wavelength range and analyzed with the Specfit program 29 using the kinetic models indicated in the corresponding section.

\section{Computational details}

DFT calculations were carried out with the Gaussian 09 (Revision D.01) ${ }^{30}$ and the BP86 functional. $\frac{31}{\mathrm{~W}}, \mathrm{P}$ and $\mathrm{S}$ centres were described with the Stuttgart RECPs and associated basis sets (with added d-orbital polarization on $\mathrm{P}(\zeta=0.387)$ and $\mathrm{S}(\zeta=0.503))$, 32 whereas the $6-31 \mathrm{G}(\mathrm{d}, \mathrm{p})$ basis set was employed for all other atoms. ${ }^{33-34}$ All stationary points were fully characterized via analytical frequency calculations, which also provided a free energy correction, computed at $298.15 \mathrm{~K}$ and $1 \mathrm{~atm}$. The free energy values in the text also include single-point corrections for the effects of the solvent (acetonitrile) using the SMD model,,$\frac{35}{}$ and dispersion effects via Grimme's D3 approximation with Becke-Johnson (BJ) damping. $\frac{36-37}{}$ The acidity of selected species in acetonitrile was evaluated by determining the logarithm of the acidic dissociation constant, i.e. $\mathrm{p} K \mathrm{a}$. Born-Haber thermodynamic cycles $\frac{38-39}{}$ were employed to determine the variation of the Gibbs free energy in solution $\left(\Delta \boldsymbol{G}_{\text {solv }}\right)$ for the proton dissociation process. To do so, the magnitudes of the free energy of the proton in the gas phase $\left(\boldsymbol{G}_{\mathrm{gas}, \mathrm{H}^{+}}\right)$and its solvation energy in acetonitrile $\left(\left(\Delta G_{\text {solv }}, \mathrm{H}^{+}\right)\right.$were taken from the literature as $-6.28 \mathrm{kcal} / \mathrm{mol} / 40$ and -260.2 $\mathrm{kcal} / \mathrm{mol}, 11$ respectively. 


\section{Acknowledgements}

The financial support of the Spanish Ministerio de Economía y Competividad and FEDER funds (Project Nos. CTQ2015-65707C2-2-P and CTQ2015-65207-P) is gratefully acknowledged. The authors also are grateful to the SCCYT of the Universidad de Cádiz and the SCIC of the Universitat Jaume I for providing the NMR and mass spectrometry facilities, respectively.

Keywords: cluster $\cdot$ aminophosphino ligand $\cdot$ kinetics $\cdot$ reaction mechanisms

[1] K. Heinze, Coord. Chem. Rev. 2015, 300, 121-141.

[2] Y. Hou, B. L. Abrams, P. C. K. Vesborg, M. E. Björketun, K. Herbst, L. Bech, A. M. Setti, C. D. Damsgaard, T. Pedersen, O. Hansen, J. Rossmeisl, S. Dahl, J. K. Nørskov, I. Chorkendorff, Nat. Mater. 2011, 10, 434-438.

[3] D. Recatalá, R. Llusar, A. L. Gushchin, E. A. Kozlova, Y. A. Laricheva, P. A. Abramov, M. N. Sokolov, R. Gómez, T. Lana-Villarreal, ChemSusChem. 2015, 8, 148-157.

[4] I. Sorribes, G. Wienhoefer, C. Vicent, K. Junge, R. Llusar, M. Beller, Angew. Chem. Int. Ed. 2012, 51, 7794-7798.

[5] E. Pedrajas, I. Sorribes, K. Junge, M. Beller, R. Llusar, ChemCatChem. 2015, 7, 2675-2681.

[6] E. Pedrajas, I. Sorribes, A. L. Gushchin, Y. A. Laricheva, K. Junge, M. Beller, R. Llusar, ChemCatChem. 2017, 9, 1128.

[7] T. F. Beltran, M. Feliz, R. Llusar, J. A. Mata, V. S. Safont, Organometallics 2011, 30, 290-297.

[8] C. Alfonso, T. F. Beltran, M. Feliz, R. Llusar, J. Cluster Sci. 2015, 26, 199-209.

[9] A. G. Algarra, M. G. Basallote, M. Feliz, M. J. Fernandez-Trujillo, E. Guillamon, R. Llusar, C. Vicent, Inor. Chem. 2006, 45, 5576-5584.

[10] A. G. Algarra, M. G. Basallote, M. Feliz, M. J. Fernandez-Trujillo, R. Llusar, V. S. Safont, Chem. Eur. J. 2006, 12, 1413-1426.

[11] A. G. Algarra, M. Feliz, M. J. Fernández-Trujillo, R. Llusar, V. S. Safont, C. Vicent, M. G. Basallote, Chem. Eur. J. 2009, 15, 4582-4594.

[12] A. G. Algarra, M. G. Basallote, M. Feliz, M. Jesus Fernandez-Trujillo, R. Llusar, V. S. Safont, Chem. Eur. J. 2010, 16, 1613-1623.

[13] A. Bacchi, M. Balordi, R. Cammi, L. Elviri, C. Pelizzi, F. Picchioni, V. Verdolino, K. Goubitz, R. Peschar, P. Pelagatti, Eur. J. Inorg. Chem. 2008, 4462-4473.

[14] W. Jia, X. Chen, R. Guo, C. Sui-Seng, D. Amoroso, A. J. Lough, K. Abdur-Rashid, Dalton Trans. 2009, 8301-8307.

[15] L. J. Hounjel, M. Bierenstiel, M. J. Ferguson, R. McDonald, M. Cowie, Inorg. Chem. 2010, 49, 4288-4300.

[16] T. Xu, D. Chen, X. Hu, Coord. Chem. Rev. 2015, 303, 32-41.

[17] T. F. Beltran, J. A. Pino-Chamorro, M. J. Fernandez-Trujillo, V. S. Safont, M. G. Basallote, R. Llusar, Inorg. Chem. 2015, 54, 607-18.

[18] C. Alfonso, M. Feliz, V. S. Safont, R. Llusar, Dalton Trans. 2016, 45, 7829-7835.

[19] T. F. Beltran, V. S. Safont, R. Llusar, Eur. J. Inorg. Chem. 2016, 5171 5179.

[20] B. Zhao, Z. Han, K. Ding, Angew. Chem. Int. Ed. 2013, 52, 47444788.

[21] J. M. John, S. Takebayashi, N. Dabral, M. Miskolzie, S. H. Bergens, J. Am. Chem. Soc. 2013, 135, 8578-8584.

[22] W. Zuo, D. E. Prokopchuk, A. J. Lough, R. H. Morris, ACS Catal. 2016, 6, 301-314.

[23] MassLynx, version 4.1 SCN 639; Copyright (C) 2008 Waters Inc.: Milford, MA (USA).

[24] CrysAlisPro, version 171.36.24; Agilent Technologies: Santa Clara, CA, 2012.
[25] R. C. Clark, J. S. Reid, Acta Crystallogr. Sect. A 1995, 51, 887-897.

[26] G. M. Sheldrick, Acta Crystallogr. Sect. A 2008, 64, 112-122.

[27] O. V. Dolomanov, L. J. Bourhis, R. J. Gildea, J. A. K. Howard, H. Puschmann, J. Appl. Crystallogr. 2009, 42, 339-341.

[28] K. Brandenburg, H. Putz, Diamond: Crystal and Molecular Structure Visualization; Crystal Impact: Bonn, Germany, 2008. http://www.crystalimpact.com/diamond

[29] R. A. Binstead, B. Jung, A. D. Zuberbühler, SPECFIT-32, Spectrum Software Associates: Chappel Hill, 2000.

[30] M. J. Frisch, G. W. Trucks, H. B. Schlegel, G. E. Scuseria, M. A Robb, J. R. Cheeseman, G. Scalmani, V. Barone, B. Mennucci, G. A Petersson, H. Nakatsuji, M. Caricato, X. Li, H. P. Hratchian, A. F. Izmaylov, J. Bloino, G. Zheng, J. L. Sonnenberg, M. Hada, M. Ehara, K. Toyota, R. Fukuda, J. Hasegawa, M. Ishida, T. Nakajima, Y. Honda, O. Kitao, H. Nakai, T. Vreven, J. A., Jr. Montgomery, J. E. Peralta, F. Ogliaro, M. Bearpark, J. J. Heyd, E. Brothers, K. N. Kudin, V. N. Staroverov, R. Kobayashi, J. Normand, K. Raghavachari, A. Rendell, J. C. Burant, S. S. lyengar, J. Tomasi, M. Cossi, N. Rega, N. J. Millam, M. Klene, J. E. Knox, J. B. Cross, V. Bakken, C. Adamo, J. Jaramillo, R. Gomperts, R. E. Stratmann, O. Yazyev, A. J. Austin, R. Cammi, C. Pomelli, J. W. Ochterski, R. L. Martin, K. Morokuma, V. G. Zakrzewski, G. A. Voth, P. Salvador, J. J. Dannenberg, S. Dapprich, A. D. Daniels, Ö. Farkas, J. B. Foresman, J. V. Ortiz, J. Cioslowski, D. J. Fox, Gaussian 09, Revision D.01; Gaussian Inc.: Wallingford CT, 2013.

[31] D. Andrae, U. Haussermann, M. Dolg, H. Stoll, H. Preuss, Theor Chim. Acta 1990, 77, 123-141.

[32] A. Hollwarth, M. Bohme, S. Dapprich, A. W. Ehlers, A. Gobbi, V. Jonas, k. F. Kohler, R. Stegmann, A. Veldkamp, G. Frenking, Chem. Physs Lett. 1993, 208, 237-240.

[33] W. J. Hehre, R. Ditchfield, J. A. Pople, J. Chem. Phys. 1972, 56 2257-2261.

[34] P. C. Harihanan, J. A. Pople, Theor. Chim. Acta 1973, 28, 213-222.

[35] A. V. Marenich, C. J. Cramer, D. G. Truhlar, J. Phys. Chem. B 2009, 113, 6378-6396.

[36] S. Grimme, J. Antony, S. Ehrlich, H. Krieg, J. Chem. Phys. 2010, 132, 154104.

[37] S. Grimme, S. Ehrlich, L. Goerigk, J. Comput. Chem. 2011, 32, 14561465.

[38] M. Born, Ber. Dtsch. Phys. Ges. 1919, 21, 13-24.

[39 F. Haber, Ber. Dtsch. Phys. Ges. 1919, 21, 750.

[40] M. D. Liptak, G. C. Shields, J. Am. Chem. Soc. 2001, 123, 7314-7319.

[41] C. P. Kelly, C. J. Cramer, D. G. Truhlar, J. Phys. Chem. B 2007, 111, 408-422.

[42] J. C. Fettinger, H. B. Kraatz, R. Poli, E. A. Quadrelli, Chem. Commun. 1997, 889-890.

[43] J. R. Fulton, A. W. Holland, D. J. Fox, R. G. Bergman, Acc. Chem. Res. 2002, 35, 137-137.

[44] M. G. Basallote, M. Feliz, M. J. Fernandez-Trujillo, R. Llusar, V. S. Safont, S. Uriel, Chem. Eur. J. 2004, 10, 1463-1471.

[45] T. F. Beltran, M. Feliz, R. Llusar, V. S. Safont, C. Vicent, Eur. J. Inorg Chem. 2013, 5797-5805.

[46] K. Hegetschweiler, M. Worle, M. D. Meienberger, R. Nesper, H. W. Schmalle, R. D. Hancock, Inorg. Chim. Acta 1996, 250, 35-47.

[47] F. A. Cotton, P. A. Kibala, M. Matusz, C. S. McCaleb, R. B. W Sandor, Inorg. Chem. 1989, 28, 2623-2630

[48] M. Sasaki, G. Sakane, T. Ouchi, T. Shibahara, J. Cluster Sci. 1998 9, 25-43.

[49] J. F. Coetzee, G. R. Padmanabhan, J. Am. Chem. Soc. 1965, 87, 5005-5010.

[50] R. G. Wilkins, Kinetics and Mechanism of Reactions of Transition Metal Complexes. Wiley: Germany, 1991, pp. 214-218. 
Entry for the Table of Contents (Please choose one layout)

Layout 1:

\section{FULL PAPER}

Whereas reaction of the cluster with $\mathrm{OH}^{-}$involves the substitution of the coordinated bromides by $\mathrm{OH}^{-}$ligands, the reactivity with $\mathrm{Et}_{3} \mathrm{~N}$ is quite different and leads to species resulting from proton abstraction at the $\mathrm{NH}_{2}$ groups of the edpp ligands. Mechanistic details are discussed on the basis of combined experimental and computational studies

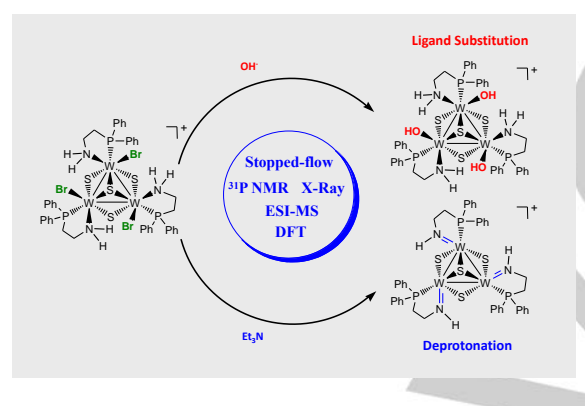

The effect of Aminophosphino ligand deprotonation

Jose A. Pino-Chamorro, [a]t Tomás F. Beltrán, ${ }^{[b] \dagger} M$. Jesús FernándezTrujillo, ${ }^{[a]}$ Manuel G. Basallote, ${ }^{*[a]}$ Rosa Llusar, $^{*[b]}$ and Andrés G. Algarra ${ }^{*[a]}$

Page No. - Page No.

Title

Layout 2:

\section{FULL PAPER}

((Insert TOC Graphic here; max. width: $11.5 \mathrm{~cm}$; max. height: $2.5 \mathrm{~cm}$; NOTE: the final letter height should not be less than $2 \mathrm{~mm}$.))

Text for Table of Contents

*one or two words that highlight the emphasis of the paper or the field of the study

\section{Key Topic*}

Author(s), Corresponding Author(s)*

Page No. - Page No.

Title 